\title{
Assessment of Mercury Concentrations and Fluxes Deposited from the Atmosphere on the Territory of the Yamal-Nenets Autonomous Area
}

\author{
Stella Eyrikh ${ }^{1, *(\mathbb{D}, \text { Liliya Shol }}{ }^{1}$ and Elena Shinkaruk ${ }^{2}$ (D) \\ 1 Institute for Water and Environmental Problems, Siberian Branch of RAS, 656038 Barnaul, Russia; \\ lilichkashol661@gmail.com \\ 2 The State Public Institution of the Yamal-Nenets Autonomous Okrug "Arctic Research Center", \\ 629008 Salekhard, Russia; elena1608197@yandex.ru \\ * Correspondence: steyrikh@gmail.com; Tel.: +7-3852-364675
}

check for

updates

Citation: Eyrikh, S.; Shol, L.;

Shinkaruk, E. Assessment of Mercury Concentrations and Fluxes Deposited from the Atmosphere on the Territory of the Yamal-Nenets Autonomous

Area. Atmosphere 2022, 13, 37. https://doi.org/10.3390/atmos 13010037

Academic Editors: Sae Yun Kwon, Hélène Angot and Yan Wang

Received: 30 October 2021

Accepted: 21 December 2021

Published: 27 December 2021

Publisher's Note: MDPI stays neutral with regard to jurisdictional claims in published maps and institutional affiliations.

Copyright: (C) 2021 by the authors. Licensee MDPI, Basel, Switzerland. This article is an open access article distributed under the terms and conditions of the Creative Commons Attribution (CC BY) license (https:// creativecommons.org/licenses/by/ $4.0 /)$.

\begin{abstract}
The problem of mercury input and its further distribution in the Arctic environment is actively debated, especially in recent times, due to the observed processes of permafrost thawing causing the enhanced release of mercury into the Arctic atmosphere and further distribution in the terrestrial and aquatic ecosystem. The atmospheric mercury deposition occurs via dry deposition and wet scavenging by precipitation events. Here we present a study of $\mathrm{Hg}$ in wet precipitation on the remote territory of the Russian Arctic; the data were obtained at the monitoring stations Nadym and Salekhard in 2016-2018. Mercury pollution of the Salekhard atmosphere in cold time is mainly determined by regional and local sources, while in Nadym, long-range transport of mercury and local fuel combustion are the main sources of pollutants in the cold season, while internal regional sources have a greater impact on the warm season. Total mercury concentrations in wet precipitation in Nadym varied from $<0.5$ to $63.3 \mathrm{ng} / \mathrm{L}$. The highest $\mathrm{Hg}$ concentrations in the springtime were most likely attributed to atmospheric mercury depletion events (AMDE). The contributions of wet atmospheric precipitation during the AMDE period to the annual $\mathrm{Hg}$ deposition were $16.7 \%$ and $9.8 \%$ in 2016/2017 and 2017/2018, respectively. The average annual volume-weighted $\mathrm{Hg}$ concentration (VWC) in the atmospheric precipitation in Nadym is notably higher than the values reported for the remote regions in the Arctic and comparable with the values obtained for the other urbanized regions of the world. Annual $\mathrm{Hg}$ fluxes in Nadym are nevertheless close to the average annual fluxes for remote territories of the Arctic zone and significantly lower than the annual fluxes reported for unpolluted sites of continental-scale monitoring networks of the different parts of the world (USA, Europe, and China). The increase of $\mathrm{Hg}$ deposition flux with wet precipitation in Nadym in 2018 might be caused by regional emissions of gas and oil combustion, wildfires, and $\mathrm{Hg}$ re-emission from soils due to the rising air temperature. The $37 \mathrm{~cm}$ increase of the seasonally thawed layer (STL) in 2018 compared to the 10-year average reflects that the climatic changes in the Nadym region might increase $\mathrm{Hg}(0)$ evasion, considering a great pool of $\mathrm{Hg}$ is contained in permafrost.
\end{abstract}

Keywords: mercury; Arctic; atmospheric wet precipitation; deposition fluxes; AMDE; permafrost thawing

\section{Introduction}

Mercury is a global pollutant that can be released into the environment both from natural sources and processes (emissions from the ocean, geothermal activities and volcanic eruptions, rock weathering, and biomass burning) [1] and anthropogenic activity (coal, oil, and natural gas combustion, mining and smelting activities, gold and silver mining, waste processing, chlor-alkali and cement industry, etc.) [2]. Currently available global emissions inventories are quite complete and accurate for some anthropogenic sources; however, there are still uncertainties in the development of mercury emission inventories 
for natural sources and the re-emission of $\mathrm{Hg}$ (existing emission estimates vary by a factor of 3) $[3,4]$. Most mercury polluting the Arctic results from air and ocean routes from sources outside the Arctic: intercontinental transport can cause up to $93 \%$ of $\mathrm{Hg}$ deposition in the Arctic $[3,5,6]$. With the existing air circulation system, pollutants are transported from sources thousands of kilometers away from the Arctic region (from the industrially developed regions of Europe, Asia, and North America) in winter, while in the summer, the contribution of meridional transport from medium-distance and local sources of pollution increases [5].

The biogeochemical cycle of mercury in the Arctic is associated with significant risks [7-10]. Once entered in the Arctic environment, $\mathrm{Hg}$ is subject to bioaccumulation in the tissues of living organisms, exerting a toxic effect on them. Moreover, biomagnification (a cumulative increase in the $\mathrm{Hg}$ concentrations as it moves up the food chain) is observed, causing the highest concentrations in top predators, including humans [11,12].

In the atmosphere, $\mathrm{Hg}$ exists in three forms: gaseous elemental $\mathrm{Hg}(0)$, reactive gaseous (RGM), and particulate-bound mercury ( $\mathrm{HgP})$. Oxidized $\mathrm{Hg}$ forms have much shorter atmospheric residence times than the most stable and dominant $\mathrm{Hg}(0)$ form, with $\mathrm{RGM}$ being deposited between hours and days and HgP being deposited within days to weeks. Accordingly, $\mathrm{Hg}(0)$ is the long-range transport form, while RGM and HgP are typically deposited locally or regionally $[13,14]$. Various forms of $\mathrm{Hg}$ are removed from the atmosphere with different efficiency by wet or dry deposition. A wet deposition involves the scavenging of gas-phase and aerosol-phase $\mathrm{Hg}(\mathrm{II})$, a dry deposition involves surface uptake of both $\mathrm{Hg}(0)$ and $\mathrm{Hg}(\mathrm{II})$ [13]. The conversion from $\mathrm{Hg}(0)$ to $\mathrm{Hg}(\mathrm{II})$ plays a key role in atmospheric and biogeochemical $\mathrm{Hg}$ cycling. Advances in atmospheric mercury, the dominant oxidation pathways in the atmosphere $\left(\mathrm{O}_{3}, \mathrm{OH}\right.$, and $\mathrm{Br}$-induced), were reviewed in the paper [15]. In the Arctic are observed so-called "atmospheric mercury depletion events" (AMDE), a phenomenon discovered in 1995 by Schroeder [16], involving a sharp decrease in $\mathrm{Hg}$ concentration in the surface layer of the atmosphere occurring during the polar spring. AMDE chemistry is similar to the tropospheric ozone depletion (ODE) phenomena. The depletion of atmospheric $\mathrm{Hg}$ is thought to be caused by $\mathrm{Hg}(0)$ oxidation by reactive halogens, namely, $\mathrm{Br}$ atoms or $\mathrm{BrO}$ radicals and $\mathrm{UV}$ radiation. It was shown that this leads to refreezing sea ice forming on open waters and snowpack within $200 \mathrm{~km}$ of sea ice, providing a large pool of reactive halogens that drives AMDE [17]. $\mathrm{Hg}(0)$ is converted to RGM and/or deposited into the snowpack. Some of the deposited RGM is then reduced to $\mathrm{Hg}(0)$ and subsequently re-emitted to the atmosphere, while some of it remains within the snowpack. There is a delicate $\mathrm{Hg}$ balance in the Arctic between atmospheric oxidation and deposition on the one hand and snowpack photo-reduction and emission on the other [18]. The study AMDE in an arctic coastal location near Ny-Ålesund, Svalbard (Norway) detected high concentrations of THg deposited onto the snow surface, reaching $373 \mathrm{ng} / \mathrm{L}$ and estimated deposition fluxes of 200-2160 ng/ ${ }^{2}$; however, most of the deposited $\mathrm{Hg}$ was re-emitted to the atmosphere via photochemical reactions [19].

Studies of mercury fate in atmospheric air, its wet and dry deposition, and distribution among environmental components in the Arctic were mainly carried out in Canadian Arctic, Greenland, Norway, and Alaska [8,20-24]. EMEP and GMOS monitoring stations, National Atmospheric Deposition Program's Mercury Deposition Network (NADP-MDN) as well as Canadian Air and Precipitation Monitoring Network (CAPMoN) undertake short- and long-term measurements of $\mathrm{Hg}$ in precipitation (wet deposition) in the Polar region in the frame of their monitoring networks [3]. Amderma is the only continuous monitoring station in the Russian Arctic where GEM was measured [25]. Hg studies focused mostly on the European part of the Russian Arctic, where the largest non-ferrous metallurgy complexes, iron ore smelting, and mining enterprises are located [26-29]. For the Siberian part, a mercury problem is observed as well, but studies are limited and are mostly related to the Russian Arctic Seas [30-32]. In the Yamal-Nenets Autonomous Area (YNAA), regional environmental monitoring has revealed the negative impact of mercury on the environment; in particular, the effects of its accumulation in vegetation and animal 
organisms [33]. Screening of the mercury content in the blood and hair of the residents of the YNAA detected an excess of the permissible level of mercury, especially among the aboriginal population consuming fish and reindeer meat $[34,35]$. There are several main possible sources of mercury in the YNAA: transboundary transport with air masses, atmospheric emissions of mercury from fires, and significant regional and local inputs from gas and oil combustion by power plants and factories. Industrial activities in the YNAA are mainly associated with the exploration, development, and operation of oil and gas fields; therefore, the region's territory is subject to technogenic impacts of varying degrees of intensity [36]. There are 4938 million tons of current explored oil reserves and 39,281 billion $\mathrm{m}^{3}$ of current explored gas reserves within the YNAA [37]. The Yamal-Nenets Autonomous Area accounts for $80 \%$ of Russia's total natural gas production and about $8 \%$ of Russian oil [34]. Arctic landscapes are characterized by low resistance to anthropogenic influences. There are pronounced manifestations of thermal degradation of the permafrost zone in some areas of the Russian Arctic. The nature of permafrost degradation depends on technogenic activities in the region, while climate change enhances their impact [38,39]. Recent studies indicated that the Arctic is a territory of the cycle of mercury with high flows and large reserves [40]. Schuster et al. estimated that soils in permafrost regions contain $1656 \pm 962 \mathrm{Gg} \mathrm{Hg}$, of which half (793 $\pm 461 \mathrm{Gg} \mathrm{Hg})$ is frozen in permafrost [41]. Permafrost contains almost twice as much mercury as all other soils, ocean and atmosphere combined, and it is ready to be released by permafrost thawing over the next century [41,42].

This work aimed to determine the level of $\mathrm{Hg}$ concentration and fluxes of wet deposition on the study region to assess seasonal and spatial differences and factors influencing these changes. We hope that this study will partly fill this gap on the map of the Russian Arctic and improve our understanding of the role of wet deposition in the mercury cycle in the Polar Regions.

\section{Materials and Methods}

\subsection{Study Area}

Atmospheric wet precipitations (rain, snow) were collected at two monitoring stations of the Scientific Research Centre of the Arctic organized at the urban areas of YNAA: Salekhard and Nadym (Figure 1). The territory of the Yamal-Nenets Autonomous Area is located in the north of Western Siberia, with about $50 \%$ of the territory above the Arctic Circle; it belongs to three climatic zones: arctic, subarctic, and temperate continental [37,43]. Situated on the territory of the Nadym lowland, it is bounded by the Polar Urals Mountains from the west and the Siberian Ridges from the south-east. Since there are no significant orographic barriers for the passage of air masses from the north and south, the development of the meridional circulation determines abrupt and rapid changes in synoptic conditions [44]. Nadym $\left(65^{\circ} 32^{\prime} \mathrm{N} 72^{\circ} 31^{\prime} \mathrm{E}\right)$ is a circumpolar city located $100 \mathrm{~km}$ south of the Arctic Circle; it is located in the central part of the YNAA in a flat area near the Gulf of Ob with the unimpeded passage of air masses. Salekhard $\left(66^{\circ} 32^{\prime} \mathrm{N} 66^{\circ} 38^{\prime} \mathrm{E}\right)$ is the capital of YNAA; this is the only city in the world that is located directly on the Arctic Circle. The climate of Salekhard is determined by its geographic location, because on the left, it is bounded by the spurs of the Ural Mountains, partially blocking the access of the warm air masses of the Atlantic. Mountain ranges intensify cyclonic activity. The climate of both study sites is subarctic continental, which is the Dfc Code according to Köppen climate classification types [45]. It is characterized by short cool summer and long and severe winter with storms and frequent snowfalls; the air temperature can drop to $-60^{\circ} \mathrm{C}$. The climate is influenced by permafrost, the proximity of the cold Kara Sea, and the abundance of bays, rivers, swamps, and lakes. Low clouds, a small number of sunny days, and deep soil freezing are observed there. Winter lasts for up to eight months, starting in October-November and ending at the end of May. Snow generally reaches its maximum depth from April to May. The polar day occurs when existing radiation inversions are eliminated; inversions in May are formed largely due to warmer air advection [44]. Total solar radiation is similar in both sites [46]; annual precipitation ranges from 400 to $500 \mathrm{~mm}$, and summer precipitation prevails over 
winter [47]. Under current climatic conditions, precipitation deposited on Nadym is formed mainly at an altitude of over $600 \mathrm{~m}$; precipitation deposited on Salekhard, on the contrary, is below $600 \mathrm{~m} \mathrm{[48].}$

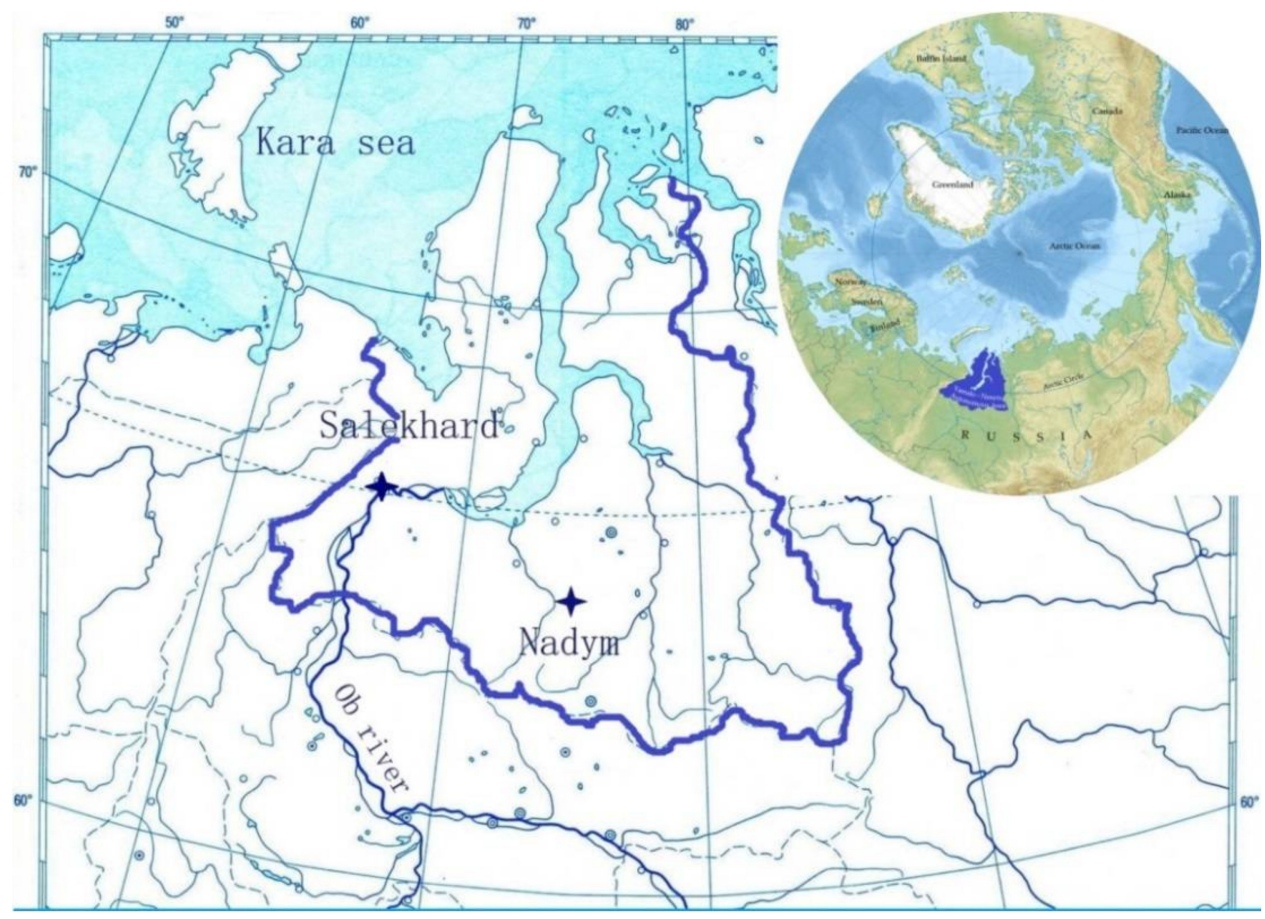

Figure 1. Study area and location of the monitoring stations.

Wet atmospheric precipitations were sampled from the end of 2016 to 2018: in the Nadym station throughout the year, and in the Salekhard station only during cold periods (owing to technical reasons). The annual distribution of the monthly precipitation and the temperature curve for the monitoring station Nadym is shown in Figure 2.

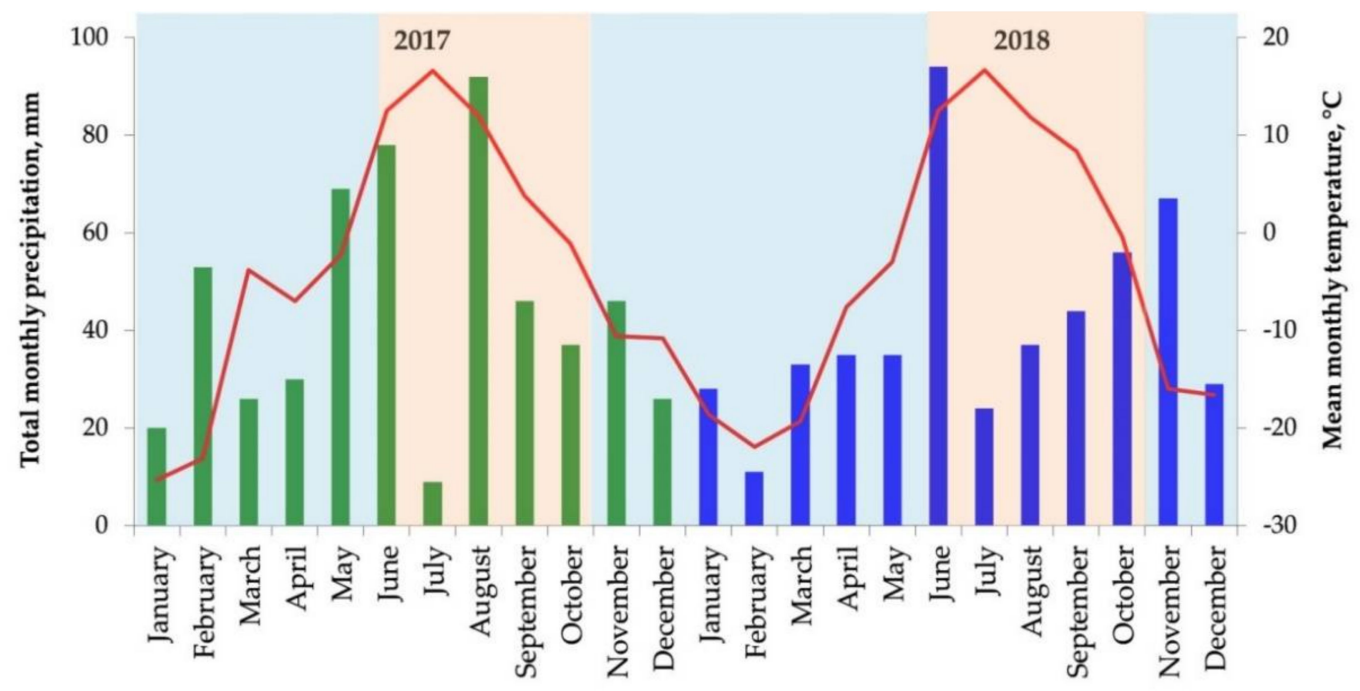

Figure 2. Mean monthly temperature (red line graph) and total monthly precipitation (bar graph, green color in 2017 and blue color in 2018) over two years for Nadym (warm periods are colored beige; cold periods are colored light blue) based on weather archive data [47]. 
In our study, the assignment of precipitation to cold and warm periods was justified by the type of precipitation (snow or rain) and air temperature during deposition and also confirmed by an analysis of the water isotopic composition. Under the current climatic conditions, precipitation in cold and warm periods was comparable: $174.1 \mathrm{~mm}$ and $241.6 \mathrm{~mm}$ (in 2016/2017); $253.8 \mathrm{~mm}$ and $211.1 \mathrm{~mm}$ (in 2017/2018), respectively. The annual amount of precipitation increased but did not change drastically in two years, amounting to $415.7 \mathrm{~mm}$ in 2016/2017 and $464.9 \mathrm{~mm}$ in 2017/2018.

\subsection{Sample Collection and Analytical Procedure}

Event-based wet precipitations (rain and snow) were collected for mercury $(\mathrm{Hg})$ and trace element analyses. Though weekly collections are much more common, event-based precipitation samples provide the best opportunity to study how mercury is scavenging from the atmosphere [49]. The type of precipitation and meteorological conditions (start and end time of precipitation collection, air temperature during precipitation, wind direction, humidity, etc.) were recorded for each precipitation event. Simultaneously samples were taken for $\mathrm{Hg}$, trace metals, and isotopic composition analysis. Details of sample preparation and the determination of stable isotope compositions $(\delta 18 \mathrm{O}$ and $\delta \mathrm{D})$ in wet precipitation are described elsewhere [50,51].

Winter precipitations (snow) were collected into high-density polyethylene plastic bags placed into a barrel equipped with blowing protection. Snow samples were melted in closed plastic containers at room temperature, followed by volume measurement and acidification by ultrapure nitric acid (produced by Savillex DST-1000) to prevent losses and absorption of $\mathrm{Hg}$ on the bottle wall $(\mathrm{pH} \leq 2)$. Since the general sample was taken to analyze $\mathrm{Hg}$ and other elements, we preferred $\mathrm{HNO}_{3}$ to the $\mathrm{HCl}$ that is more conventional for mercury analysis but has an interfering influence on the determination of other trace elements by ICPMS. Rain and mixed (rain and snow) precipitations were collected by a hand-made sampler placed into the barrel with blowing protection about $1.5 \mathrm{~m}$ above the ground to avoid contamination of the sample during heavy rains. The collector consisted of a $20 \mathrm{~cm}$ glass funnel connected with an HDPE bottle with a silicone tube. The volume of rain samples was measured, and samples were acidified by ultrapure $\mathrm{HNO}_{3}$ similarly snow samples. Unfiltered acidified samples of wet atmospheric precipitation were transported to the Chemical Analytical Center of the Institute for Water and Environmental Problems of the Siberian Branch of the Russian Academy of Science (IWEP SB RAS) for further analysis.

Handling the laboratory samples was undertaken on a mercury-free clean bench. Five $\mathrm{mL} / \mathrm{L} \mathrm{BrCl}$ solution was added to samples at least $24 \mathrm{~h}$ before analysis to determine the total mercury according to Method US EPA 1631 [52]. The sample preparation procedure was controlled by using the "field blank" and "method blank" prepared from MilliQ water (18 $\mathrm{M} \Omega \mathrm{cm}$ quality). The total mercury concentrations were determined by Cold Vapor Atomic Fluorescence Spectrometry using mercury analyzer "Mercur DUO Plus" (Analytik Jena, Jena, Germany) with a detection limit of $0.5 \mathrm{ng} / \mathrm{L}$. Quality control was carried out following the US EPA 1631 and fully complied with the accepted quality criteria of the method (Table 1).

Table 1. QA/QC quality criteria of the US EPA 1631 method.

\begin{tabular}{ccc}
\hline \multicolumn{1}{c}{ Parameter } & Methodological Criteria & Results \\
\hline \multicolumn{1}{c}{ Initial and Ongoing Precision and Recovery (IPR), \% } \\
\hline $\begin{array}{c}\text { Residual Standard deviation } \\
\text { (RSD) } \\
\text { Recovery }\end{array}$ & 21 & $<5$ \\
\multicolumn{2}{c}{ Matrix Spike/Matrix Spike Duplicate (MS and MSD), \% } \\
\hline $\begin{array}{c}\text { Relative Percent Difference } \\
\text { (RPD) } \\
\text { Recovery }\end{array}$ & 24 & $96-101$ \\
\hline
\end{tabular}




\subsection{Calculation of Hg Volume-Weighted Concentration and Wet Deposition Flux}

It should be noted that values below the detection limit were included in the calculation of average values estimated as half a detection limit value [53].

For a representative assessment of the level of mercury pollution in atmospheric precipitation, it is advisable to use volume-weighted concentrations (VWC) calculated using the Equation (1) for each precipitation event, taking into account the contribution of each event to the annual water equivalent:

$$
C_{V W C}=\frac{\sum C_{i} \times P_{i}}{\sum P}
$$

where $C_{i}$ is $\mathrm{Hg}$ concentration in the $\mathrm{i}$-th sample $(\mathrm{ng} / \mathrm{L}) ; P_{i}$-the amount of $\mathrm{i}$-th sample in water equivalent $(\mathrm{mm}) ; P$; - the total amount of precipitation for the season or year in water equivalent (mm).

A quantitative assessment of the mercury deposition on the underlying surface was carried out by calculating deposition fluxes (2) for different years and seasons.

$$
F=\frac{C \times P \times 0.1}{S}
$$

where $F$ is the $\mathrm{Hg}$ flux $\left(\mu \mathrm{g} / \mathrm{m}^{2}\right)$ with wet atmospheric precipitation; $C$ - the concentration of $\mathrm{Hg}$ in the sample $(\mu \mathrm{g} / \mathrm{L}) ; \mathrm{P}$ - the amount of precipitation in water equivalent $(\mathrm{mm})$; and $S$-sampler area $\left(\mathrm{dm}^{2}\right)$.

Data were processed using Microsoft Excel 2010 software. Student's $t$-test was applied to evaluate VWCs and Fluxes differences for different monitoring stations and seasons. Differences were assessed as statistically significant at $p<0.05$.

\section{Results and Discussion}

\subsection{Hg Concentrations in Wet Atmospheric Precipitation of Yamal-Nenets Autonomous Area}

The results of total mercury determination in wet atmospheric precipitation in the cities of Nadym and Salekhard are given in Table 2. Mercury concentration in Nadym precipitation varied from $1 \mathrm{ng} / \mathrm{L}$ to $29.4 \mathrm{ng} / \mathrm{L}$ in a warm period and from $<0.5 \mathrm{ng} / \mathrm{L}$ (less than the detection limit) to $63.3 \mathrm{ng} / \mathrm{L}$ in a cold one, with the maximum concentration in the springtime (middle of May). In Salekhard, the $\mathrm{Hg}$ concentration range in a cold period is smaller, possibly because late spring samples were not collected; therefore, the highest $\mathrm{Hg}$ concentrations may have been missed.

Table 2. Average values, ranges, and volume-weighted concentrations (VWC) of Hg in wet atmo-

\begin{tabular}{|c|c|c|c|c|c|}
\hline \multirow{2}{*}{ City } & \multicolumn{4}{|c|}{ Hg Concentration, $\mathrm{Ng} / \mathrm{L}$} & \multirow{2}{*}{ Period } \\
\hline & Min & Max & Average & VWC & \\
\hline \multicolumn{6}{|c|}{ Cold period } \\
\hline \multirow{2}{*}{ Salekhard } & 1.5 & 26.1 & 6.6 & 5.4 & 5 October 2016-01 May 2017* \\
\hline & 1.2 & 20.4 & 5.5 & 5.6 & 1 November 2017-18 April 2018 * \\
\hline \multirow{2}{*}{ Nadym } & $<0.5$ & 27.5 & 6.3 & 6.6 & 26 October 2016-29 May 2017 \\
\hline & $<0.5$ & 63.3 & 14.8 & 8.6 & 14 October 2017-03 July 2018 \\
\hline \multicolumn{6}{|c|}{ Warm period } \\
\hline \multirow{2}{*}{ Nadym } & 3.7 & 22.6 & 8.6 & 6.3 & 30 May 2017-13 October 2017 \\
\hline & 1.0 & 29.4 & 12.2 & 10.5 & 4 July 2018-12 October 2018 \\
\hline
\end{tabular}
spheric precipitation of Salekhard and Nadym in different seasons and years.

The minimal and maximal $\mathrm{Hg}$ concentrations differ insignificantly between periods, excluding short-term high increases in springtime. The comparison of average concentrations in Nadym and Salekhard in the same cold periods showed that $\mathrm{Hg}$ concentrations 
were similar in 2016/2017 and differed almost three times in 2017/2018, which might be explained by the incomplete sampling period in Salekhard. Moreover, average concentrations are often overestimated due to the disproportional contribution of weak short-term precipitation with high concentrations of pollutants. At the same time, VWC represents the pollution level more objectively, accounting for the real contribution of each event in total annual precipitation [49]. VWCs of mercury in atmospheric precipitation in both sites are similar, though VWCs in Salekhard are lower than in Nadym for both years; however, the difference is statistically significant only in the cold period 2017/2018. Besides the reason related to incomplete sampling, the orographic features of the city's location and differences in the cloud height where precipitations were formed might influence the levels of atmospheric pollution of Nadym and Salekhard in the winter period. In Nadym, precipitation is formed mainly at an altitude of over $600 \mathrm{~m}$; in Salekhard, on the contrary, below $600 \mathrm{~m}$ [48]. This difference is confirmed by the excess sulfates (ex- $\mathrm{SO}_{4}{ }^{2-}$ ) analysis previously conducted at the same locations, which are indicators of anthropogenic pollution of the atmosphere. The content of ex- $\mathrm{SO}_{4}{ }^{2-}$ (\% of total sulfates) in the cold period was 37 and 19 in 2016/2017, and 34 and 8 in 2017/2018 for Salekhard and Nadym, respectively [48]. Thus, the pollution of the Salekhard atmosphere is determined mainly by regional and local sources throughout the year, while in Nadym, in the cold period, the main source of pollutants is long-range transport and local fuel combustion; in the warm season, on the contrary, internal regional sources make a greater contribution.

\subsection{Seasonal and Interannual Changes of $\mathrm{Hg}$ Concentrations in Atmospheric Precipitation in Nadym}

Most studies report that wet mercury deposition is higher in warm seasons, and this has been attributed to more precipitation [54]. However, it should be noted that most studies compare the calendar periods of the year (winter, spring, summer, and autumn), i.e., the $\mathrm{Hg}$ concentrations over the corresponding three-month periods [37,54]. Indeed, summer precipitation is 1.8-2.3 times greater than the precipitation in winter (depending on the study year). However, in fact, winter in Siberia lasts much longer than three months; therefore, we consider it possible to divide the periods according to the type of precipitation (rain and snow). In such a case, precipitation in cold and warm periods is quite comparable: $174.1 \mathrm{~mm}$ and $241.6 \mathrm{~mm}$ (in 2016/2017); $253.8 \mathrm{~mm}$ and $211.1 \mathrm{~mm}$ (in 2017/2018) in cold and warm periods, respectively. The seasonal dynamic of VWCs of mercury in atmospheric precipitation in Nadym is shown in Figure 3. In 2016/2017 VWCs were at the same level in the cold and warm periods (differences weren't statistically significant). An increase was observed in the cold period, and an even larger increase was observed in the warm period (differences were statistically significant), indicating the evident rise of $\mathrm{Hg}$ concentration in $2017 / 2018$.

Hg pollution in Nadym in cold periods is related to long-range transport and local emissions from fuel and waste combustion. The region's sources of atmospheric moisture precipitated in the Nadym Lowland during the cold period of 2016-2017 were determined based on the joint analysis of synoptic, trajectory, and isotopic data: the Atlantic Ocean (35.7\%), the North Atlantic Ocean, and the Arctic Ocean (30.4\%), the Black Sea-Caspian region (20\%), and inland regions (about 10\%) [51].

In a warm period of the year, when the meridional transport of air masses is enhanced, the mercury level is determined by its regional background and emissions from the medium-distance intercontinental sources. Therefore, in the warm season, elevated $\mathrm{Hg}$ concentrations may be associated with wildfires in the tundra; also, it is worth considering such a possible $\mathrm{Hg}$ source as the release of mercury during the warming up of the tundra surface [41,42], which will be discussed in more detail below, in Section 3.3. 


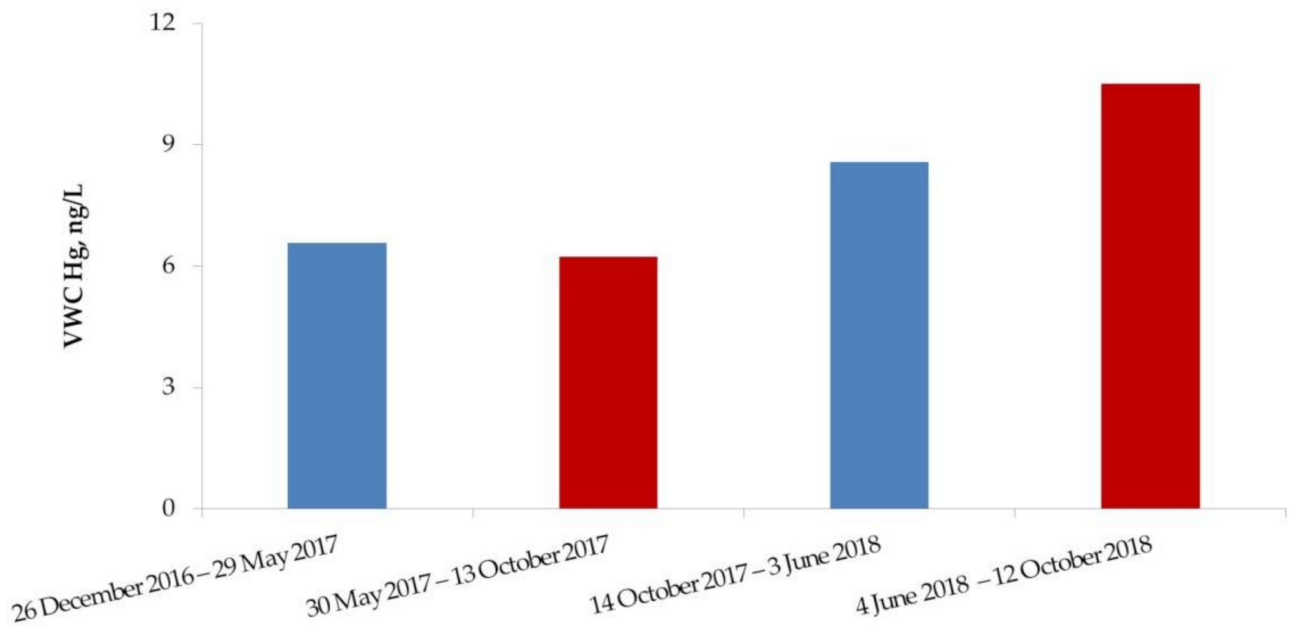

Figure 3. Seasonal volume-weighted concentrations of mercury (ng/L) in wet atmospheric precipitation in Nadym in the 2016-2018 years, red and blue colors correspond to warm and cold periods, respectively.

Annual Hg VWCs in wet precipitation in Nadym were 6.7 and $10.0 \mathrm{ng} / \mathrm{L}$, demonstrating an increase of about $56 \%$ from $2016 / 2017$ to $2017 / 2018$. This result is at odds with a downward trend of mercury concentrations in the air and atmospheric deposition observed in recent years at many monitoring stations in the United States, Canada, and Europe that is explained by a decrease in anthropogenic emissions [23,24,55-57]. Significant long-term temporal trends in precipitation mercury concentrations were found at 34 of the $135 \mathrm{MDN}$ sites investigated, with $\sim 88 \%$ of significant trends showing decreases in VWCs [58]. However, if there was a downward trend in the eastern part of the United States, the changes were insignificant or increased in the western part, despite the absence of an increase in local mercury emissions [23]. For remote areas of the Canadian Arctic and Alaska, it was shown that interannual variability during the studied period is insignificant [53]. In the last ten years, only slight changes in mercury deposition fluxes were observed in high northern latitudes (above $60^{\circ} \mathrm{N}$ ) - from -0.9 to $+0.1 \%$ per year [55]. The study of heavy metals and mercury content in the atmosphere and atmospheric precipitation of the Arctic territories has been actively carried out in different years by scientists from other countries, including Russia $[22,25,54,59,60]$. Comparison of $\mathrm{Hg}$ concentrations in atmospheric precipitation in the city of Nadym with remote areas of the Arctic showed that both the median and the two-year average VWC of mercury in Nadym are at a higher level, whereas the annual fluxes are pretty comparable (Table 3).

Table 3. Concentrations and fluxes of mercury in wet atmospheric precipitation in Nadym and other remote Arctic locations.

\begin{tabular}{ccccc}
\hline \multirow{2}{*}{ Location } & \multicolumn{2}{c}{ Hg Concentration, $\mathbf{n g} / \mathbf{L}$} & \multirow{2}{*}{$\begin{array}{c}\text { Annual } \\
\text { Flux, } \boldsymbol{\mu g} / \mathbf{m}^{2}\end{array}$} & Study Period \\
\cline { 2 - 3 } & Median & Annual VWC & & \\
\hline Nadym, Russia [this study] & 6.7 & 8.3 & 3.6 & $2016-2018$ \\
\hline Dalniye Zelentsy, Russia [29] & - & 6.0 & 3.0 & $2001-2002$ \\
\hline Ny-Ålesund, Norway [54] & - & 4.5 & 1.1 & $2012-2015$ \\
\hline Pallas, Finland [54] & - & 6.1 & 2.1 & $2011-2014$ \\
\hline Nome, USA [53] & 3.5 & 6.2 & 2.3 & $2013-2015$ \\
\hline Glacier Bay National Park, USA [53] & 1.8 & 1.9 & 3.0 & $2010-2013$ \\
\hline Dutch Harbor, USA [53] & 2.3 & 2.9 & 4.5 & $2009-2015$ \\
\hline Gates of the Arctic National Park, USA [53] & 3.6 & 6.0 & 2.1 & $2008-2015$ \\
\hline
\end{tabular}


Due to the limited available data, we compare the values obtained in different years, realizing that this is not quite objective. We need more data for a reliable assessment of mercury's spatial and temporal input with wet deposition. The average VWC of mercury in atmospheric precipitation in Nadym, calculated over two years, is comparable with values reported for other urbanized areas [61-66] (Figure 4), although it is significantly lower than those reported for heavily air-polluted cities, such as Shanghai, China (median 113, range 1-987 ng/L) [67].

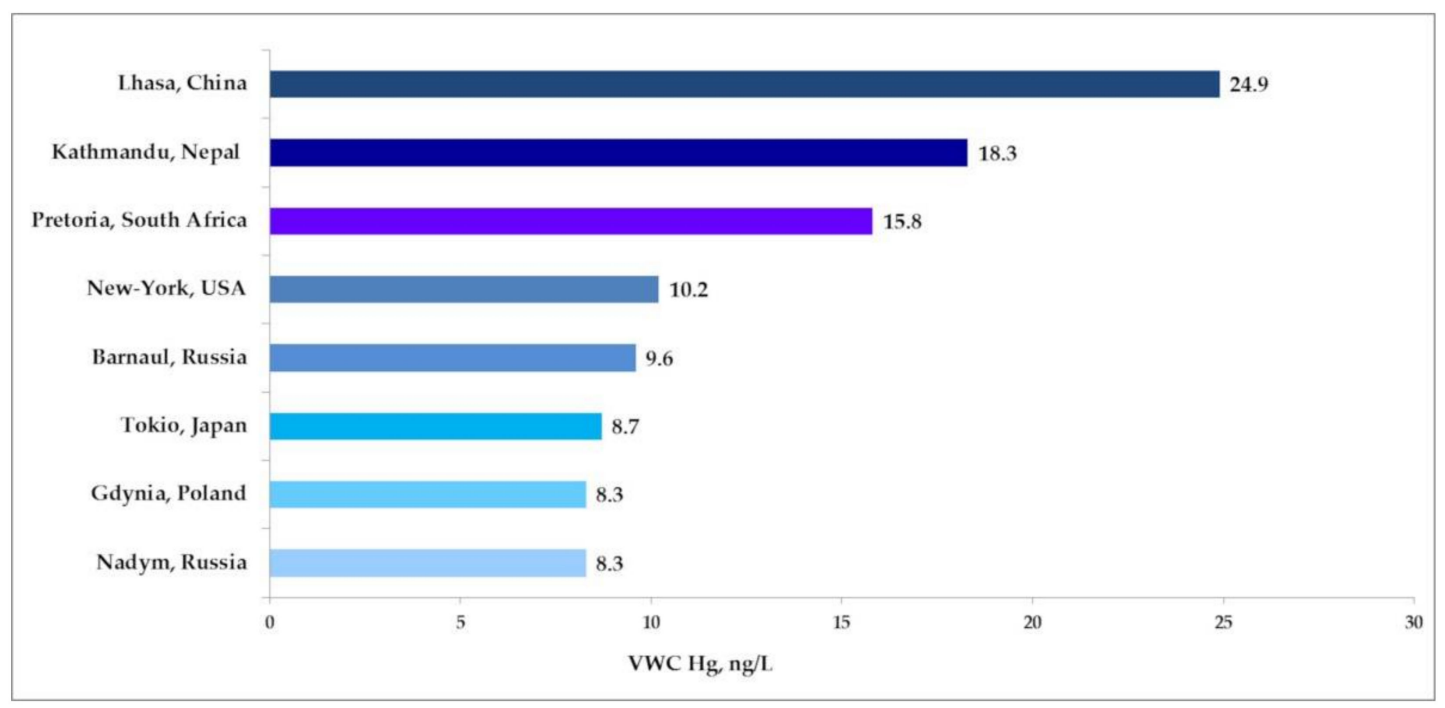

Figure 4. Annual volume-weighted concentrations of $\mathrm{Hg}$ in wet precipitation in various urbanized areas, $\mathrm{ng} / \mathrm{L}$ (the intensity of the colour is proportional to the $\mathrm{Hg}$ concentration).

\subsection{Wet Deposition Flux}

Most of the $\mathrm{Hg}$ deposition (93\%) in the Arctic is thought to be caused by intercontinental transport from the global $\mathrm{Hg}$ pool [6]. The annual wet deposition fluxes were $2.7 \mu \mathrm{g} / \mathrm{m}^{2}$ and $4.4 \mu \mathrm{g} / \mathrm{m}^{2}$ in 2016/2017 and 2017/2018, respectively. It was shown in the Northern Hemisphere that interannual differences in $\mathrm{THg}$ wet deposition are mostly linked with precipitation volume [54]. Annual precipitation increased slightly (session 2.1), whereas $\mathrm{Hg}$ wet deposition increase was more pronounced. The main contributor to atmospheric pollution in the Arctic in 2018 was Russia (52\%), including internal sources located in the Arctic [68]. Sources from Kazakhstan take the second position in pollution of the Arctic by heavy metals (12\%) despite the long distance from the Arctic. The global character of $\mathrm{Hg}$ pollution explains the high contribution of sources of other world (23\%). The average annual deposition flux for the studied period was $3.6 \mu \mathrm{g} / \mathrm{m}^{2}$. A North-South $\mathrm{Hg}$ deposition gradient changes from $0.2 \mu \mathrm{g} / \mathrm{m}^{2}$ in the northern tundra Alaska $\left(68.6^{\circ} \mathrm{N}\right)$ [69] to $4.8 \mu \mathrm{g} / \mathrm{m}^{2}$ in the south $\left(57.7^{\circ} \mathrm{N}\right)$ [53], and Nadym located at $65.3^{\circ} \mathrm{N}$ fits well here. $\mathrm{Hg}$ deposition flux in Nadym is comparable to the remote territories of the Arctic zone (see session 3.2, Table 3), but it was found to be significantly lower than averaged assessments in other regions (North America-9.5 $\mu \mathrm{g} / \mathrm{m}^{2}$, Europe- $6.8 \mu \mathrm{g} / \mathrm{m}^{2}$, Australia- $5 \mu \mathrm{g} / \mathrm{m}^{2}$, China-4.8 and $12.6 \mu \mathrm{g} / \mathrm{m}^{2}$ in remote and urban sites, respectively) [3,70-72].

Seasonal $\mathrm{Hg}$ wet deposition fluxes are presented in Figure 5, along with atmospheric wet precipitation. Fluxes of $\mathrm{Hg}$ varied from 1.14 to $2.22 \mu \mathrm{g} / \mathrm{m}^{2}$ and increased in 2017/18. The marked increase in wet $\mathrm{Hg}$ deposition during the warm season of 2018 cannot be attributed to increased precipitation, since precipitations were lower in the warm period than in the cold one in 2017/2018. Transboundary transport of Hg with the western and southwestern air masses prevails only in winter, and this did not change drastically from 2017 to 2018 [68]. Assessment of pollution emitted to the atmosphere from stationary sources of pollution in the YNAA (enterprises of the oil industry, mining, and processing 
of minerals, the fuel and energy complex) amounted to 786 thousand tons in 2018 that is $9 \%$ less than in 2017 [36]. Local pollution from gas and oil combustion is also possible. Although Russia has a 95\% standard for using associated petroleum gas and high fines for excess flaring, this is still happening. As a result of the flaring of associated gas in Russia, on average, one ton of produced oil accounts for about $8 \mathrm{~kg}$ of emissions of harmful substances, including mercury [73]. For example, in 2018, Tekhneftinvest was fined RUB 1.2 million for flaring more than 358 thousand cubic meters of associated petroleum gas in the YNAA. Wildfires also make a certain contribution to atmospheric $\mathrm{Hg}$ emissions every year. In summer, air masses entered from the side of the continent where the tundra and forests were burning mostly in June and July [74]. The annual area of wildfires in Siberia is about five million hectares; according to existing estimates, the annual atmospheric emission of mercury from fires in Siberia may amount to 2.7 tons [75]. Terrestrial lichens and mosses might be largely saturated with mercury in the northern regions. However, it should be noted that the annual area of wildfires did not rise substantially in 2018 [76]; moreover, the location of fires was closer to the study area in 2017.

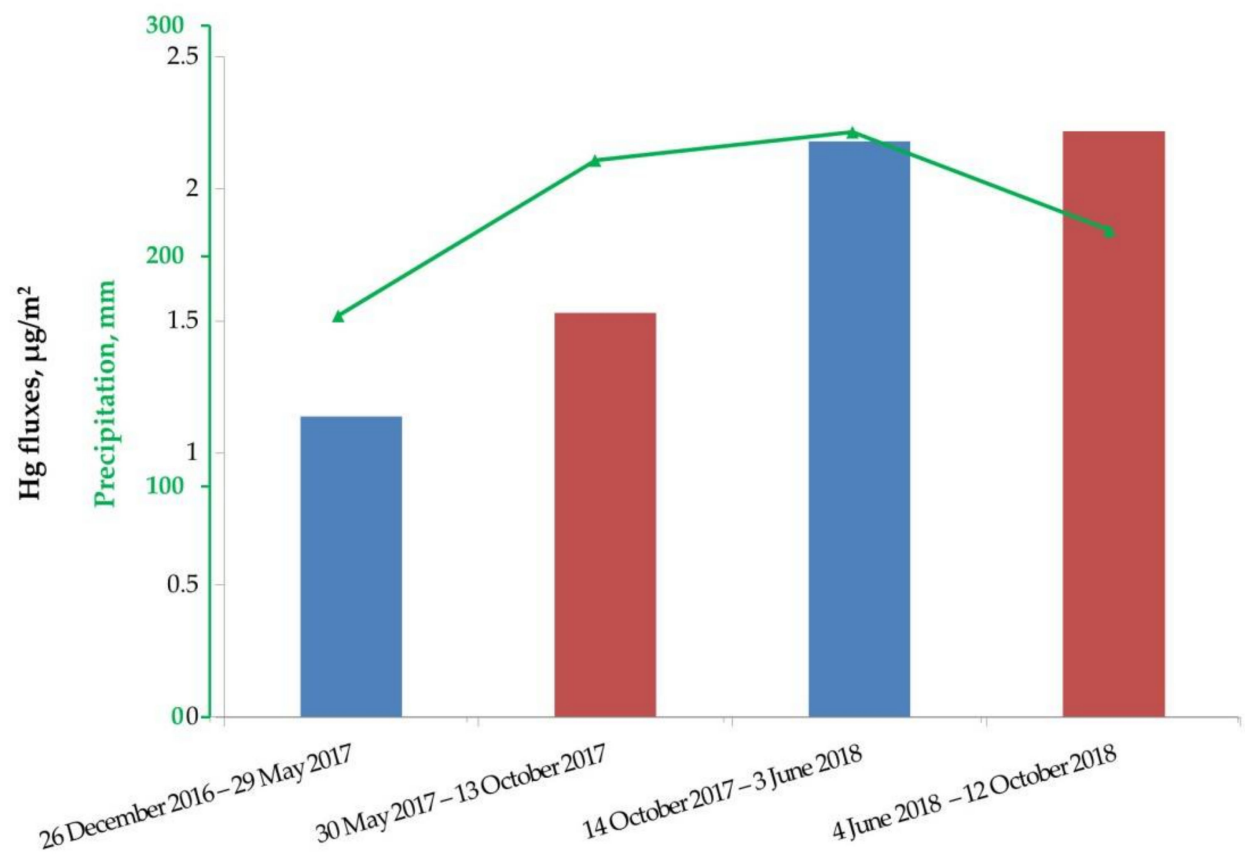

Figure 5. Seasonal atmospheric wet precipitation in Nadym ( $\mathrm{mm}$, green triangles) and fluxes of $\mathrm{Hg}$ wet deposition $\left(\mu \mathrm{g} / \mathrm{m}^{2}\right.$, red and blue colors correspond to warm and cold periods, respectively).

One more hypothesis is that the increase of $\mathrm{Hg}$ flux reflects regional input caused by high temperatures in this period. In general, in the Northern Hemisphere, the spring and summer periods of 2018 were the second warmest periods since 1958. In the Arctic, 2018 was very warm (the second in a row since 1936), the anomaly of the average annual air temperature in the latitudinal zone of $60-70^{\circ} \mathrm{N}$ (to which Nadym belongs) was $2.1^{\circ} \mathrm{C}$ [77]. The empirical model developed on six mercury flux datasets from different terrestrial sites predicted the impact of climate change on terrestrial mercury air-surface exchange. $\mathrm{Hg}$ flux is expected to increase by between $15 \%$ and $43 \%$ for a $1-2{ }^{\circ} \mathrm{C}$ temperature rise by 2050 and $15-96 \%$ for a temperature rise between $1-3.7{ }^{\circ} \mathrm{C}$ by 2100 [78]. Re-emission of $\mathrm{Hg}$ from soils is shown to be higher at higher temperatures: soil warming and winter freeze-thaw cycles increased soil $\mathrm{Hg}(0)$ evasion by $31 \%$ and 35\%, respectively, relative to the control plots [79]. Mercury in permafrost soils represents an environmental risk as a great reservoir of $\mathrm{Hg}$ containing nearly twice as much $\mathrm{Hg}$ as in all other soils, the ocean, and the atmosphere combined [41]. There was a 30-year lag between the start of large-scale permafrost thaw in the 1990s and the increase in $\mathrm{Hg}(0)$ evasion after 2020 [42]. The indicator of the state of 
permafrost soils reflecting the climatic changes is the thickness of the seasonally thawed layer (STL). In the Nadym region in 2018, the STL thickness increased substantially to $30 \mathrm{~cm}$ compared to 2017 and $37 \mathrm{~cm}$ compared to the 10-year average STL being the most significant in Western Siberia [77]. Since permafrost is continuing to thaw, the increase in $\mathrm{Hg}(0)$ evasion might be expected.

\subsection{Spring Increase of Mercury Concentrations in Wet Precipitation}

Atmospheric mercury depletion events (AMDEs) are observed in springtime throughout the Arctic.

This process is considered to be the main factor in the discharge of mercury from the atmosphere, which leads to its deposition on the surface of snow and ice in the coastal zone of the Arctic seas and can lead to additional input in the Arctic from tens to hundreds of tons of $\mathrm{Hg}$ annually $[18,19]$. Currently, deposition of $\mathrm{Hg}$ during AMDEs is typically inferred from concentrations of $\mathrm{THg}$ in the snowpack and not primarily through direct measurements of dry or wet deposition [22]. Research undertaken between 2011 and 2015 showed that AMDE is evenly distributed from April to May (38\% each) [80]. On the territory of the Russian Arctic, a similar study was carried out at the Amderma station (near the coast of the Kara Sea), where, since 2010, AMDE has also been recorded in the winter seasons, when there is no direct solar radiation [81]. It was shown that for the spring season, the number of AMDEs doubled from 23.2 to $40.4 \%$, and for the winter season, the number of AMDEs increased 10-fold from 0.2 to $26.9 \%$ from 2001 to 2013 [32].

In our study, the maximum values in wet precipitation samples were found in the spring, most likely associated with the AMDE phenomenon. Figure 6 shows the $\mathrm{Hg}$ concentrations change in atmospheric precipitation in Nadym, demonstrating a considerable influence of AMDE on $\mathrm{Hg}$ deposition with wet precipitation.

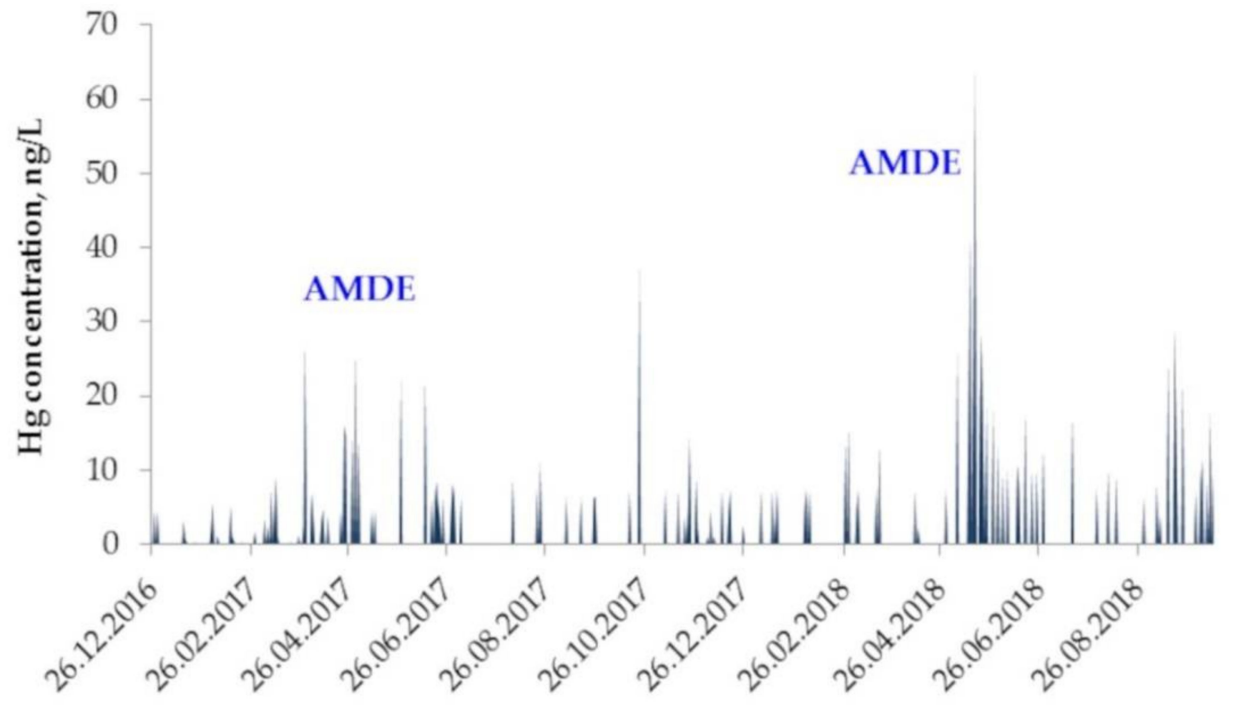

Figure 6. Mercury concentrations in wet precipitation in Nadym during AMDE.

Deposition fluxes were calculated to assess the contribution of atmospheric precipitation during the AMDE period to the total annual mercury deposition. The contribution of wet precipitation during the AMDE in the total annual wet precipitation was $16.7 \%$ in 2016/2017 and 9.8\% in 2017/2018 (Figure 7). This is higher than the values calculated by Obrist and colleagues [69], which demonstrated minor contributions from the deposition of $\mathrm{Hg}$ (II) from precipitation or AMDEs ( $<5 \%$ ), and most of the $\mathrm{Hg}$ (about $70 \%)$ in the interior Arctic tundra is derived from $\mathrm{Hg}(0)$ deposition. It should be emphasized that this study was based on the comprehensive $\mathrm{Hg}$ deposition mass balance using isotope data; whereas, we calculated the contribution without taking into account dry $\mathrm{Hg}$ deposition. 


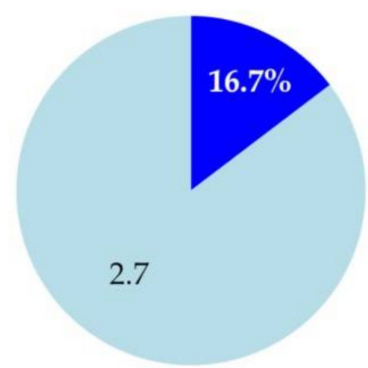

$2017-2018$

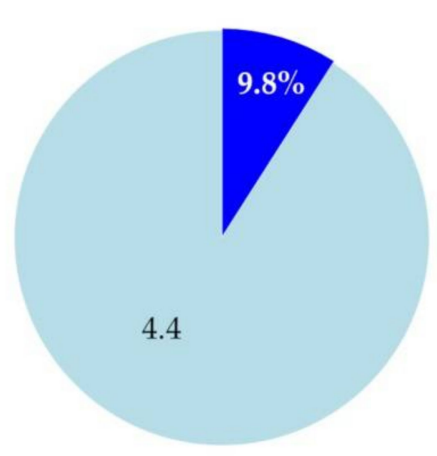

Figure 7. AMDE contribution (dark blue) in total annual $\mathrm{Hg}$ wet deposition in Nadym (light blue), where the ratio of the circle sizes corresponds to the ratio of the annual $\mathrm{Hg}$ wet deposition values.

\section{Conclusions}

This study has shown that regional differences in $\mathrm{Hg}$ concentration and deposition in the Arctic can be substantial on temporal and spatial scales. Mercury concentrations in atmospheric wet precipitation in Nadym are higher than in Salekhard because the pollution of the Salekhard atmosphere is determined mainly by regional and local sources. In contrast, the main source of pollutants in Nadym is long-range transport in cold periods that is confirmed by the results of excess sulfates $\left(e x-\mathrm{SO}_{4}{ }^{2-}\right)$ analysis as indicators of anthropogenic pollution of the atmosphere.

The highest $\mathrm{Hg}$ concentrations observed in the Nadym station in the springtime are most likely attributed to Atmospheric Mercury Depletion Events (AMDE). The contributions of atmospheric precipitation during the AMDE period to the annual $\mathrm{Hg}$ wet deposition were $16.7 \%$ and $9.8 \%$ in $2016 / 2017$ and $2017 / 2018$, respectively.

The average annual VWC in wet atmospheric precipitation in Nadym is comparable with the values obtained for other urbanized regions of the world; however, it is much higher than the values reported for remote Arctic places. However, $\mathrm{Hg}$ annual deposition flux in Nadym is comparable to remote territories of the Arctic zone and less than annual fluxes in continental-scale monitoring networks of other parts of the world (USA, Europe, and China).

At many monitoring stations in the United States, Canada, and Europe, a downward trend of mercury concentrations in the air and atmospheric deposition were observed in recent years. In the Nadym region, the increase of $\mathrm{Hg}$ concentrations and deposition fluxes in wet atmospheric precipitation in 2017/2018 comparing 2016/2017 was observed. This might be explained by the possible regional atmospheric mercury emissions from fires, gas and oil combustion. Another likely hypothesis is that mercury released from the soils caused warming in 2018, since the re-emission of $\mathrm{Hg}$ from soils is known to be higher when the temperature rises. The increase in the thickness of the seasonally thawed layer from 2017 to 2018 reached $30 \mathrm{~cm}$ in the Nadym region. Further study is required to confirm this hypothesis and identify the trend of $\mathrm{Hg}$ deposition with wet atmospheric precipitation on the territory of the Russian Arctic.

Since the wet deposition of mercury is an important part of its overall balance, the results of field observations can be used for model calculations and understanding the atmospheric circulation of $\mathrm{Hg}$ at high latitudes.

Author Contributions: Conceptualization, E.S.; methodology, E.S. and S.E.; investigation, L.S. and E.S.; writing—original draft preparation, E.S. and L.S.; writing—review and editing, E.S.; visualization, L.S.; resources and funding acquisition, E.S. and S.E. All authors have read and agreed to the published version of the manuscript. 
Funding: This study was carried out within the framework of the State assignment of the Institute for Water and Environmental Problems SB RAS.

Institutional Review Board Statement: Not applicable.

Informed Consent Statement: Not applicable.

Data Availability Statement: Not applicable.

Acknowledgments: The authors are grateful to Biol.Sci. Agbalyan Elena and colleagues of the Sector for Ecological and Biological Research of the State Institution of the YNAA for the sampling and cooperation.

Conflicts of Interest: The authors declare no conflict of interest.

\section{References}

1. Mason, R.P. Mercury Emissions from Natural Processes and Their Importance in the Global Mercury Cycle. In Mercury Fate and Transport in the Global Atmosphere; Masson, R., Pirrone, N., Eds.; Springer: Boston, MA, USA, 2009; pp. 173-191. [CrossRef]

2. $\quad$ Pirrone, N.; Cinnirella, S.; Feng, X.; Finkelman, R.B.; Friedli, H.R.; Leaner, J.; Mason, R.; Mukherjee, A.B.; Stracher, G.B.; Streets, D.G.; et al. Global mercury emissions to the atmosphere from anthropogenic and natural sources. Atmos. Chem. Phys. Discuss. 2010, 10, 5951-5964. [CrossRef]

3. AMAP; UN Environment. Technical Background Report for the Global Mercury Assessment 2018; United Nations Environment Programme: Geneva, Switzerland; Arctic Monitoring and Assessment Programme: Oslo, Norway, 2019; p. 426.

4. Pacyna, J.M.; Travnikov, O.; De Simone, F.; Hedgecock, I.M.; Sundseth, K.; Pacyna, E.G.; Steenhuisen, F.; Pirrone, N.; Munthe, J.; Kindbom, K. Current and future levels of mercury atmospheric pollution on a global scale. Atmos. Chem. Phys. Discuss. 2016, 16, 12495-12511. [CrossRef]

5. AMAP. Assessment 2011: Mercury in the Arctic; Arctic Monitoring and Assessment Programme (AMAP): Oslo, Norway, 2011; p. 193.

6. Ilyin, I.; Rozovskaya, O.; Travnikov, O. Assessment of Heavy Metal. Transboundary Pollution on Global, Regional and National Scales. In EMEP Status Report; Joint MSC-E \& CCC; Meteorological Synthesizing Centre—East (MSC-E): Moscow, Russia, 2018; p. 69.

7. Macdonald, R. Climate Change, Risks and Contaminants: A Perspective from Studying the Arctic. Hum. Ecol. Risk Assess. Int. J. 2005, 11, 1099-1104. [CrossRef]

8. Douglas, T.A.; Loseto, L.L.; Macdonald, R.W.; Outridge, P.; Dommergue, A.; Poulain, A.; Amyot, M.; Barkay, T.; Berg, T.; Chételat, J.; et al. The fate of mercury in Arctic terrestrial and aquatic ecosystems, a review. Environ. Chem. 2012, 9, 321-355. [CrossRef]

9. Poissant, L.; Zhang, H.H.; Canário, J.; Constant, P. Critical review of mercury fates and contamination in the arctic tundra ecosystem. Sci. Total Environ. 2008, 400, 173-211. [CrossRef]

10. Sundseth, K.; Pacyna, J.M.; Banel, A.; Pacyna, E.G.; Rautio, A. Climate Change Impacts on Environmental and Human Exposure to Mercury in the Arctic. Int. J. Environ. Res. Public Health 2015, 12, 3579-3599. [CrossRef]

11. Atwell, L.; Hobson, K.A.; Welch, H.E. Biomagnification and bioaccumulation of mercury in an arctic marine food web: Insights from stable nitrogen isotope analysis. Can. J. Fish. Aquat. Sci. 1998, 55, 1114-1121. [CrossRef]

12. Rigét, F.; Braune, B.; Bignert, A.; Wilson, S.; Aars, J.; Born, E.; Dam, M.; Dietz, R.; Evans, M.; Evans, T.; et al. Temporal trends of $\mathrm{Hg}$ in Arctic biota, an update. Sci. Total Environ. 2011, 409, 3520-3526. [CrossRef]

13. Driscoll, C.T.; Mason, R.; Chan, H.M.; Jacob, D.J.; Pirrone, N. Mercury as a Global Pollutant: Sources, Pathways, and Effects. Environ. Sci. Technol. 2013, 47, 4967-4983. [CrossRef] [PubMed]

14. Travnikov, O. Atmospheric Transport of Mercury. In Environmental Chemistry and Toxicology of Mercury; John Wiley \& Sons, Inc.: Hoboken, NJ, USA, 2012; pp. 331-365.

15. Lyman, S.N.; Cheng, I.; Gratz, L.E.; Weiss-Penzias, P.; Zhang, L. An updated review of atmospheric mercury. Sci. Total Environ. 2020, 707, 135575. [CrossRef]

16. Schroeder, W.H.; Anlauf, K.G.; Barrie, L.A.; Lu, J.Y.; Steffen, A.T.; Schneeberger, D.R.; Berg, T. Arctic springtime depletion of mercury. Nat. Cell Biol. 1998, 394, 331-332. [CrossRef]

17. Simpson, W.R.; von Glasow, R.; Riedel, K.; Anderson, P.; Ariya, P.; Bottenheim, J.; Burrows, J.; Carpenter, L.J.; Frieß, U.; Goodsite, M.E.; et al. Halogens and their role in polar boundary-layer ozone depletion. Atmos. Chem. Phys. Discuss. 2007, 7, 4375-4418. [CrossRef]

18. Steffen, A.; Douglas, T.; Amyot, M.; Ariya, P.; Aspmo, K.; Berg, T.; Bottenheim, J.; Brooks, S.; Cobbett, F.; Dastoor, A.; et al. A synthesis of atmospheric mercury depletion event chemistry in the atmosphere and snow. Atmos. Chem. Phys. Discuss. 2008, 8, 1445-1482. [CrossRef]

19. Skov, H.; Christensen, J.H.; Goodsite, M.E.; Heidam, N.Z.; Jensen, B.; Wåhlin, P.; Geernaert, G. Fate of Elemental Mercury in the Arctic during Atmospheric Mercury Depletion Episodes and the Load of Atmospheric Mercury to the Arctic. Environ. Sci. Technol. 2004, 38, 2373-2382. [CrossRef] 
20. Dommergue, A.; Ferrari, C.P.; Amyot, M.; Brooks, S.; Sprovieri, F.; Steffen, A. Spatial coverage and temporal trends of atmospheric mercury measurements in Polar Regions. In Mercury Fate and Transport in the Global Atmosphere: Emissions, Measurements and Models; Mason, R., Pirrone, N., Eds.; Springer: Boston, MA, USA, 2009; pp. 293-321.

21. Douglas, T.; Amyot, M.; Barkay, T.; Berg, T.; Chételat, J.N.; Dommergue, A.; Evans, M.; Ferrari, C.; Gantner, K.; Nson, M.J.; et al. What is the Fate of Mercury Entering the Arctic Environment. In AMAP Assessment 2011: Mercury in the Arctic; Arctic Monitoring and Assessment Programme (AMAP): Oslo, Norway, 2011; pp. 45-65.

22. Steffen, A.; Lehnherr, I.; Cole, A.; Ariya, P.; Dastoor, A.; Durnford, D.; Kirk, J.; Pilote, M. Atmospheric mercury in the Canadian Arctic. Part I: A review of recent field measurements. Sci. Total Environ. 2015, 509-510, 3-15. [CrossRef] [PubMed]

23. Weiss-Penzias, P.S.; Gay, D.A.; Brigham, M.E.; Parsons, M.T.; Gustin, M.S.; Ter Schure, A. Trends in mercury wet deposition and mercury air concentrations across the U.S. and Canada. Sci. Total Environ. 2016, 568, 546-556. [CrossRef] [PubMed]

24. Cole, A.S.; Steffen, A.; Eckley, C.S.; Narayan, J.; Pilote, M.; Tordon, R.; Graydon, J.A.; Louis, V.L.S.; Xu, X.; Branfireun, B.A. A Survey of Mercury in Air and Precipitation across Canada: Patterns and Trends. Atmosphere 2014, 5, 635-668. [CrossRef]

25. Steffen, A.; Schroeder, W.; Macdonald, R.W.; Poissant, L.; Konoplev, A. Mercury in the arctic atmosphere: An analysis of eight years of measurements of GEM at Alert (Canada) and a comparison with observations at Amderma (Russia) and Kuujjuarapik (Canada). Sci. Total Environ. 2005, 342, 185-198. [CrossRef]

26. Danilov, A.A.; Evseev, A.V.; Gordeev, V.V.; Kochemasov, Y.V.; Lukyanov, Y.S.; Lystsov, V.N.; Moiseenko, T.I.; Murashko, O.A.; Nemirovskaya, I.A.; Patin, S.A.; et al. Diagnostic Analysis of the Environmental Status of the Russian Arctic (Advanced Summary); Scientific World: Moscow, Russia, 2011.

27. Zhulidov, A.V.; Robarts, R.D.; Pavlov, D.F.; Kämäri, J.; Gurtovaya, T.Y.; Meriläinen, J.J.; Pospelov, I.N. Long-term changes of heavy metal and sulphur concentrations in ecosystems of the Taymyr Peninsula (Russian Federation) North of the Norilsk Industrial Complex. Environ. Monit. Assess. 2011, 181, 539-553. [CrossRef]

28. Vasilevich, M.I.; Vasilevich, R.S.; Gabov, D.N.; Kondratenok, B.M. Evaluation of aerial technogenic pollution near industrial enterprises in the tundra zone (by the example of Vorkuta city). Геоэкология Инженерная геологияГидрогеология. Геокриология 2019, 6, 94-105. [CrossRef]

29. Golubeva, N.I.; Matishov, G.G.; Burtseva, L.V. Precipitation of heavy metals in the Barents Sea region. Dokl. Earth Sci. 2005, 401, 469-472.

30. Ji, X.; Abakumov, E.; Xie, X. Atmosphere-ocean exchange of heavy metals and polycyclic aromatic hydrocarbons in the Russian Arctic Ocean. Atmos. Chem. Phys. Discuss. 2019, 19, 13789-13807. [CrossRef]

31. Ivanov, M. Mercury in the bottom sediments of the Chukotka Sea and adjacent Arctic areas. In Geology and Geoecology of Eurasian Continental Margins. Special Issue. Geology and Mineral Resources of the Eurasian Marginal Seas; GEOS: Moscow, Russia, 2012; pp. 81-87.

32. Pankratov, F. Dynamics of Atmospheric Mercury in the Russian Arctic. Ph.D. Thesis, Moscow State University, Moscow, Russia, 2015.

33. Agbalyan, E.V.; Listishenko, A.A. Accumulation of pollutants (mercury and cadmium) in soil, plants and animals. Scientific bulletin of the YNAO. Ecol. Yamalo-Nenets Auton. Okrug 2017, 3, 4-10.

34. Agbalyan, E. Monitoring of national security: The priorities and some results of studies of the state of the environment in the Yamal-Nenets Autonomous Okrug. Bus. Mag. Neftegaz.RU 2018, 10, 118-125.

35. Agbalyan, E.V.; Shinkaruk, E. The mercury content in the blood of inhabitants of the yamalo-nenets autonomous district. Hyg. Sanit. 2018, 97, 799-802. [CrossRef]

36. State Report On the State and Protection of the Environment of the Russian Federation in 2018; Ministry of Natural Resources of Russia: Moscow, Russia; NPP Cadastre: Yaroslavl, Russia, 2019; p. 844.

37. The State Report On the State and Environmental Protection of the Russian Federation in 2016; Ministry of Natural Resources of Russia: Moscow, Russia; NIA-Nature: Moscow, Russia, 2017; p. 760.

38. Petrov, S.; Mamaeva, N.; Gabdullin, M.; Kraev, A. The Ecological Situation in the Russian Arctic Permafrost Zone. MATEC Web Conf. 2016, 73, 5008. [CrossRef]

39. Мамаева, Н.Л.; Петров, С.А. Natural and anthropogenic dynamics of permafrost soils in the areas of oil and gas production in yamalo-nenets autonomous okrug. Oil Gas Stud. 2015, 6, 99-104. [CrossRef]

40. Bishop, K.; Shanley, J.B.; Riscassi, A.; de Wit, H.A.; Eklöf, K.; Meng, B.; Mitchell, C.; Osterwalder, S.; Schuster, P.F.; Webster, J.; et al. Recent advances in understanding and measurement of mercury in the environment: Terrestrial Hg cycling. Sci. Total Environ. 2020, 721, 137647. [CrossRef]

41. Schuster, P.F.; Schaefer, K.M.; Aiken, G.R.; Antweiler, R.C.; DeWild, J.F.; Gryziec, J.D.; Gusmeroli, A.; Hugelius, G.; Jafarov, E.E.; Krabbenhoft, D.P.; et al. Permafrost Stores a Globally Significant Amount of Mercury. Geophys. Res. Lett. 2018, 45, $1463-1471$. [CrossRef]

42. Schaefer, K.; Elshorbany, Y.; Jafarov, E.; Schuster, P.F.; Striegl, R.G.; Wickland, K.P.; Sunderland, E.M. Potential impacts of mercury released from thawing permafrost. Nat. Commun. 2020, 11, 1-6. [CrossRef]

43. Geography of Yamal. Available online: https://www.yanao.ru/region/geography/ (accessed on 15 September 2021).

44. Kalinin, V.M.; Kozin, B.V.; Larin, S.I.; Osipov, V.A.; Popova, T.V.; Soromotina, O.V.; Starkov, V.D. Geography of the Yamal-Nenets Autonomous Okrug; Tyumen State University Publishing House: Tyumen, Russia, 2001. 
45. Arnfield, A.J. Köppen climate classification, in Encyclopedia Britannica. 11 November 2020. Available online: https://www. britannica.com/science/Koppen-climate-classification (accessed on 12 December 2021).

46. Average Daily Incident Shortwave Solar Energy. Available online: https://weatherspark.com/compare/y/107495 \{\}106461/ Comparison-of-the-Average-Weather-in-Nadym-and-Salekhard\#Figures-SolarEnergy (accessed on 2 December 2021).

47. Archive of Weather in Nadym. Available online: https://rp5.ru/Weather_in_Yamalo-Nenets_Autonomous_Okrug (accessed on 4 September 2021).

48. Papina, T.S. Assessment of the transboundary transport of pollutants to the territory of the Yamal-Nenets Autonomous Okrug. In Obdoria. Modern Scientific Research in the Arctic; Siberian Branch of the Russian Academy of Sciences: Salekhard, Russia, 2018; p. 38.

49. Kaulfus, A.S.; Nair, U.S.; Holmes, C.D.; Landing, W.M. Mercury Wet Scavenging and Deposition Differences by Precipitation Type. Environ. Sci. Technol. 2017, 51, 2628-2634. [CrossRef] [PubMed]

50. Papina, T.S.; Eirikh, A.N.; Malygina, N.S.; Eyrikh, S.S.; Ostanin, O.V.; Yashina, T.V. Microelement and stable isotopic composition of snowpack in the katunsky biosphere reserve (altai republic). Ice Snow 2018, 58, 41-55. [CrossRef]

51. Malygina, N.S.; Eyrikh, A.N.; Agbalyan, E.V.; Papina, T.S. Isotopic composition and source regions of winter precipitation in the Nadym Lowland. Ice Snow 2020, 60, 98-108.

52. US EPA. Method 1631, Revision E: Mercury in Water by Oxidation, Purge and Trap, and Cold Vapor Atomic Fluorescence Spectrometry; U.S. Environmental Protection Agency, Office of Water, Office of Science and Technology, Engineering and Analysis Division (4303): Washington, DC, USA, 2002; p. 38.

53. Pearson, C.; Howard, D.; Moore, C.; Obrist, D. Mercury and trace metal wet deposition across five stations in Alaska: Controlling factors, spatial patterns, and source regions. Atmos. Chem. Phys. Discuss. 2019, 19, 6913-6929. [CrossRef]

54. Sprovieri, F.; Pirrone, N.; Bencardino, M.; D’Amore, F.; Angot, H.; Barbante, C.; Brunke, E.-G.; Arcega-Cabrera, F.; Cairns, W.; Comero, S.; et al. Five-year records of mercury wet deposition flux at GMOS sites in the Northern and Southern hemispheres. Atmos. Chem. Phys. Discuss. 2017, 17, 2689-2708. [CrossRef]

55. Zhang, Y.; Jacob, D.J.; Horowitz, H.M.; Chen, L.; Amos, H.M.; Krabbenhoft, D.P.; Slemr, F.; Louis, V.L.S.; Sunderland, E.M Observed decrease in atmospheric mercury explained by global decline in anthropogenic emissions. Proc. Natl. Acad. Sci. USA 2016, 113, 526-531. [CrossRef]

56. Muntean, M.; Janssens-Maenhout, G.; Song, S.; Selin, N.E.; Olivier, J.G.; Guizzardi, D.; Maas, R.; Dentener, F. Trend analysis from 1970 to 2008 and model evaluation of EDGARv4 global gridded anthropogenic mercury emissions. Sci. Total Environ. 2014, 494-495, 337-350. [CrossRef] [PubMed]

57. Obrist, D.; Kirk, J.L.; Zhang, L.; Sunderland, E.M.; Jiskra, M.; Selin, N.E. A review of global environmental mercury processes in response to human and natural perturbations: Changes of emissions, climate, and land use. Ambio 2018, 47, 116-140. [CrossRef]

58. Olson, C.I.; Fakhraei, H.; Driscoll, C.T. Mercury Emissions, Atmospheric Concentrations, and Wet Deposition across the Conterminous United States: Changes over 20 Years of Monitoring. Environ. Sci. Technol. Lett. 2020, 7, 376-381. [CrossRef]

59. Munthe, J.; Wängberg, I.; Rognerud, S.; Fjeld, E.; Verta, M.; Porvari, P.; Meili, M. Mercury in Nordic Ecosystems; IVL-B-1761; The Swedish Environmental Research Institute Ltd.: Stockholm, Sweden, 2007.

60. Sanei, H.; Outridge, P.; Goodarzi, F.; Wang, F.; Armstrong, D.; Warren, K.; Fishback, L. Wet deposition mercury fluxes in the Canadian sub-Arctic and southern Alberta, measured using an automated precipitation collector adapted to cold regions. Atmos. Environ. 2010, 44, 1672-1681. [CrossRef]

61. Siudek, P.; Falkowska, L.; Brodecka, A.; Kowalski, A.; Frankowski, M.; Siepak, J. Mercury in precipitation over the coastal zone of the southern Baltic Sea, Poland. Environ. Sci. Pollut. Res. 2014, 22, 2546-2557. [CrossRef]

62. Huang, J.; Kang, S.; Wang, S.; Wang, L.; Zhang, Q.; Guo, J.; Wang, K.; Zhang, G.; Tripathee, L. Wet deposition of mercury at Lhasa, the capital city of Tibet. Sci. Total Environ. 2013, 447, 123-132. [CrossRef]

63. Sakata, M.; Marumoto, K. Wet and dry deposition fluxes of mercury in Japan. Atmos. Environ. 2005, 39, 3139-3146. [CrossRef]

64. Tripathee, L.; Guo, J.; Kang, S.; Paudyal, R.; Huang, J.; Sharma, C.; Zhang, Q.; Chen, P.; Ghimire, P.S.; Sigdel, M. Spatial and temporal distribution of total mercury in atmospheric wet precipitation at four sites from the Nepal-Himalayas. Sci. Total Environ. 2019, 655, 1207-1217. [CrossRef] [PubMed]

65. Zhou, H.; Zhou, C.; Hopke, P.K.; Holsen, T.M. Mercury wet deposition and speciated mercury air concentrations at rural and urban sites across New York state: Temporal patterns, sources and scavenging coefficients. Sci. Total Environ. 2018, 637-638, 943-953. [CrossRef]

66. Gichuki, S.W.; Mason, R. Mercury and metals in South African precipitation. Atmos. Environ. 2013, 79, 286-298. [CrossRef]

67. Shi, G.; Chen, Z.; Teng, J.; Li, Y. Spatio-temporal variation of total mercury in precipitation in the largest industrial base in China: Impacts of meteorological factors and anthropogenic activities. Tellus B Chem. Phys. Meteorol. 2015, 67, 25660. [CrossRef]

68. Travnikov, O.; Batrakova, N.; Gusev, A.; Ilyin, I.; Kleimenov, M.; Rozovskaya, O.; Shatalov, V.; Strijkina, I.; Aas, W.; Breivik, K.; et al. Assessment of Transboundary Pollution by Toxic Substances: Heavy Metals and POPs. In EMEP Status Report; Joint MSC-E \& CCC \& CEIP Report; Meteorological Synthesizing Centre-East (MSC-E): Moscow, Russia, 2020; p. 149.

69. Obrist, D.; Agnan, Y.; Jiskra, M.; Olson, C.L.; Colegrove, D.P.; Hueber, J.; Moore, C.W.; Sonke, J.; Helmig, D. Tundra uptake of atmospheric elemental mercury drives Arctic mercury pollution. Nat. Cell Biol. 2017, 547, 201-204. [CrossRef] [PubMed]

70. Fisher, J.A.; Nelson, P.F. Atmospheric mercury in Australia: Recent findings and future research needs. Elem. Sci. Anthr. 2020, 8 , 70. [CrossRef] 
71. Fu, X.; Yang, X.; Lang, X.; Zhou, J.; Zhang, H.; Yu, B.; Yan, H.; Lin, C.-J.; Feng, X. Atmospheric wet and litterfall mercury deposition at urban and rural sites in China. Atmos. Chem. Phys. Discuss. 2016, 16, 11547-11562. [CrossRef]

72. Prestbo, E.M.; Gay, D.A. Wet deposition of mercury in the U.S. and Canada, 1996-2005: Results and analysis of the NADP mercury deposition network (MDN). Atmos. Environ. 2009, 43, 4223-4233. [CrossRef]

73. Kiryushin, P.A.; Knizhnikov, A.Y.; Kochi, K.V.; Puzanova, T.A.; Uvarov, S.A. Associated petroleum gas in Russia: "You can't burn it, recycle it!" In Analytical Report on the Economic and Environmental Costs of Associated Gas Flaring in Russia; World Wildlife Fund (WWF): Moscow, Russia, 2013; p. 88.

74. Global Wildfire Information System (GWIS). Available online: https://gwis.jrc.ec.europa.eu/apps/country.profile/maps (accessed on 1 December 2021).

75. Shcherbov, B.L. The role of forest floor in migration of metals and artificial nuclides during forest fires in Siberia. Contemp. Probl. Ecol. 2012, 5, 191-199. [CrossRef]

76. Arctic Region I Wildfires Overview 2015-2020-Emergency Response Coordination Centre (ERCC); ECHO. 2021. Available online: https://erccportal.jrc.ec.europa.eu/ercmaps/ECDM_20210308_Arctic_ForestFires_Emissions.pdf (accessed on 10 December 2021).

77. A Report on Climate Features on the Territory of the Russian Federation in 2018; Russian Federal Service for Hydrometeorology and Environmental Monitoring (Roshydromet): Moscow, Russia, 2019; p. 79.

78. Macsween, K.; Edwards, G.; Howard, D. Up-scaling mercury emissions from terrestrial surfaces as a response to sustained temperature increase. Atmos. Environ. 2019, 223, 117190. [CrossRef]

79. Yang, Y.; Meng, L.; Yanai, R.D.; Montesdeoca, M.; Templer, P.H.; Asbjornsen, H.; Rustad, L.E.; Driscoll, C.T. Climate change may alter mercury fluxes in northern hardwood forests. Biogeochemistry 2019, 146, 1-16. [CrossRef]

80. Angot, H.; Dastoor, A.; De Simone, F.; Gårdfeldt, K.; Gencarelli, C.N.; Hedgecock, I.M.; Langer, S.; Magand, O.; Mastromonaco, M.N.; Nordstrøm, C.; et al. Chemical cycling and deposition of atmospheric mercury in polar regions: Review of recent measurements and comparison with models. Atmos. Chem. Phys. Discuss. 2016, 16, 10735-10763. [CrossRef]

81. Pankratov, F.; Mahura, A.; Popov, V.; Katz, O. Increase of winter atmospheric mercury depletion events during long-term monitoring of mercury in the Russian Arctic. In State of Arctic Seas and Territories under Climate Change; NArFU: Arkhangel'sk, Russia, 2014. 